University of Wollongong

Research Online

Faculty of Business - Papers (Archive)

Faculty of Business and Law

2014

CEO duality structure and firm performance in Pakistan

Qaiser Rafique Yasser

Universiti Malaysia Sarawak

Abdullah Al Mamun

University of Wollongong, amamun@uow.edu.au

Abdul Suriya

Follow this and additional works at: https://ro.uow.edu.au/buspapers

Part of the Business Commons

Research Online is the open access institutional repository for the University of Wollongong. For further information contact the UOW Library: research-pubs@uow.edu.au 


\title{
CEO duality structure and firm performance in Pakistan
}

\begin{abstract}
This article examines the impact of CEO duality on firm performance; which attracted much attention, especially in emerging economies, yet yielded several inconsistent empirical results. CEO duality exists when the offices of the CEO and Chairman are retained by the same person. This study examines the relationship between CEO duality and the performance of Pakistani public listed companies by using a sample of five years, from 2007 to 2011 . This study tested the hypotheses with data obtained from the Karachi Stock Exchange 100 indexed firms, and employed the agency and stewardship theory perspectives. However, our empirical results do not show a significant relationship between CEO duality and firm performance, but CEO qualification and CEO affiliation are positively associated with firm performance. The results suggest that CEO duality is a less significant issue in corporate governance than suggested by many previous researchers and policy makers. The paper contributes to the literature on corporate governance and firm performance by introducing a framework in identifying and analyzing moderating variables that affect the relationship between CEO duality and firm performance.
\end{abstract}

\section{Keywords}

duality, structure, firm, ceo, performance, pakistan

Disciplines

Business

\section{Publication Details}

Yasser, Q. R., Al Mamun, A. \& Suriya, A. R. (2014). CEO duality structure and firm performance in Pakistan. Asian Journal of Accounting and Governance, 5 57-69. 


\title{
CEO Duality Structure and Firm Performance in Pakistan
}

\author{
QAISER RAFIQUE YASSER, ABDULlaH Al MAMUN \& ABDUl RAHIM SURIYA
}

\begin{abstract}
This article examines the impact of CEO duality on firm performance; which attracted much attention, especially in emerging economies, yet yielded several inconsistent empirical results. CEO duality exists when the offices of the CEO and Chairman are retained by the same person. This study examines the relationship between CEO duality and the performance of Pakistani public listed companies by using a sample of five years, from 2007 to 2011. This study tested the hypotheses with data obtained from the Karachi Stock Exchange 100 indexed firms, and employed the agency and stewardship theory perspectives. However, our empirical results do not show a significant relationship between CEO duality and firm performance, but CEO qualification and CEO affiliation are positively associated with firm performance. The results suggest that CEO duality is a less significant issue in corporate governance than suggested by many previous researchers and policy makers. The paper contributes to the literature on corporate governance and firm performance by introducing a framework in identifying and analyzing moderating variables that affect the relationship between CEO duality and firm performance.
\end{abstract}

Keywords: CEO duality; firm performance; Pakistan

\section{INTRODUCTION}

The term "Duality" describes the corporate leadership structure where one person holds both the positions of CEO and Board Chairman in an organization (Finkelstein \& D'Aveni 1994; Abdullah 2004; Wang et al. 2014; Arslan et al. 2014); and it has become an emerging issue of research in the current era following corporate scandals around the world (Elsayed 2007; Michael \& Anurag 2007; Peng, Zhang \& Li 2007; Iyengar \& Zampelli 2009; Chahine \& Tohmé 2009; Tuggle, Sirmon, Reutzel \& Bierman 2010). Interestingly, ten out of these corporate collapses in early 2000, eight had the CEO/Chairman duality (Albrecht \& Albrecht 2004).

The terminology 'CEO duality' in the literature is diverse. The dual position (CEO and chairman is the same individual) is also referred to as combined $\mathrm{CEO} / \mathrm{Chairman}$ (Finkelstein \& D'Aveni 1994; Judge et al. 2003 and Lam \& Lee 2008), CEO-chair duality (Bhagat \& Bolton, 2008), unitary leadership structure (Brickley et al. 1997), joint CEO/chairman (Daily \& Dalton 1997), and CEO as chairman, among others.

This paper principally investigates the relationship between CEO/Chairman duality and the performance of Pakistani public listed companies. The other attributes of the CEO have also been taken into consideration and their effect on firm performance investigated. As for the U.S.'s firms, they have pragmatic dominant board leadership structure, as observed in $70 \%$ to $80 \%$ of them (Rechner \& Dalton 1991 and Rhoades et al. 2001). Conversely, almost 90\% of London Stock Exchange companies separate these two offices (Kang \& Zaardkoohi 2005).
The major contribution of this study is that it provides auxiliary empirical evidence lending support to the espousal of good corporate governance practices such as prescribed by the Cadbury Committee (1992) and related guidelines. A further contribution made by this study is that it provides fresh evidence from an emerging market, Pakistan. Pakistan revamped its corporate governance structure in 2002 through the issuance of code of corporate governance and a revised code issued in 2012 by the Securities and Exchange Commission of Pakistan (SECP). The first code (2002) suggests the separation of CEO and Chairman's offices, but the latest code used the phrase "must be separated" for both positions.

Thus, we intend to address the question of whether the separation of the roles of CEO and chairman contributes to the corporate performance of public listed companies in Pakistan. In doing this, we aim to contribute to the literature in two ways. First, by specifically examining CEO duality, a setting that has been more frequently analyzed in the context of multiple governance prescriptions. Second, by offering more topical evidence of potential relevance to emerging economies, and to Pakistan in particular.

\section{ARGUMENTS SUPPORTING CEO DUALITY}

A unifying theme of the various arguments in support of duality is that combining the CEO and Chairman positions boosts the board's effectiveness. Donaldson \& Davis (1991) argued that the stewardship theory offers a complementary perspective, by stating that agents are good stewards to organization's resources. Stewardship 
theorists advocated that there is no inherent conflict of interest between agents and principals because, among other reasons, CEOS will not risk their reputation and career by pursuing interests that collide with the shareholders. The CEO also derives job satisfaction from non-tangible enticements such as professional reputation, industry recognition, goodwill, career advancement and authority. These motivations uphold the alignment of interests and ruin management opportunism.

A related theory is that dual leadership structure reduces the cost of information transfer between the company's decision makers. The combined CEO position avoids the need for the transfer of information that must take place if different individuals hold the two positions. Since the information transfer may be costly, untimely, or incomplete, having significant information residing in dual role may press forward the ability of that individual to perform the strategic role.

The supporters of duality also argue that a combined position provides a combined command structure, single focal point and reduces the company's cost in decision making. A CEO-Chair can exert greater authority and speed in making and implementing strategic decisions for the company, creating the image of stability. Thus, decisions made by a CEO-Chair on an important issue may be clearer, timelier, projecting a clear sense of direction, and more consistent than decisions made by a CEO who has to negotiate and consult with a board that is led by a separate Chair. Moreover, having only an individual occupying both the CEO and Chair positions reduces public confusion on who is in charge of the company, and clarifies who is responsible for the firm's performance and long term sustainability.

\section{ARGUMENTS OPPOSING CEO/CHAIRMAN DUALITY}

The agency theorists stated that the separation between the roles of the CEO and Chairman (Judge et al. 2003) safeguards accountability and blight the board's ability to monitor managerial opportunism because CEO has the propensity to control the board (Daily \& Dalton 1993; Wang et al. 2014). Agency theory supporters argued that separation enhances the board's effectiveness in management responsibilities by improving both the superiority and the suitability of decision making. A nonexecutive board Chairperson may bring fresh knowledge, self-determination and insights to the board's decisionmaking process which provides distinctive outlooks that enhance the board's ability in its management duties to deliberate and make strategic and fundamental business decisions.

Charan (2005) argues that duality minimizes the risk of entrenchment due to the lack of motivation and incentive to objectively evaluate and discipline the dual executive; which increase the risk of entrenching the CEO-Chair in both positions. However, dual positions' entrenchment, in turn, increases the potential for this powerful executive to use the corporation to further his own private interests instead of furthering common shareholder wellbeing.

In a company where the chairman of the board is also the CEO of the company, the powers will be concentrated onto one individual and the possibility for the checking and balancing of CEOs' power are virtually eliminated. In such corporation, the board of director may not be able to function as an independent body, where that is the purpose of the board. Taking the agency theory's perspective, separating the role of CEO and chairman will decrease the opportunity for the CEO and inside directors to exercise behaviors which are self-motivated and costly to the provision of finance (Principal).

Stewart et al. (1991) has also proposed on the necessary separation of CEO and board chairman functions; one individual cannot perform both roles effectively as both roles have their distinctive domain.

\section{CEO DUALITY IN PAKISTAN}

Corporate governance system in Pakistan is possibly less evolved than those in Anglo-American countries, Germany, or Japan. In the intervening time, emerging economies as a whole differ substantially from developed countries in terms of their institutional, regulatory and legal background (Prowse 1999). Nonetheless, there are substantial divergence in corporate governance frameworks and practices between Pakistan and most developing economies. The development of corporate governance mechanisms depends on the social, political, cultural and historical characteristics of a country (Prowse 1999). Pakistan carries the legacy of being nearly two hundred years under British colonial rule. This resulted in similar administrative style, as far as corporate governance is concerned. Besides, it allows Pakistan to inherit an English-style institutional and regulatory framework in the form of a Companies Act.

Pakistan is a common law country having one tier board structure and the mainstream public companies display concentrated ownership pattern with family or/ and holding company ownership. In several instances, controlling group controls the firms directly or employs an outsider CEO, but the family's head or elder is exerted as Chairman of the Board. Meanwhile, business atmosphere in Pakistan is illustrated by the influence of dominant controlling shareholders, minority representation and management, in favor of the first. In order to improve the corporate governance environment in Pakistan, an array of institutional and regulator inventiveness have been implemented as a result of the monumental corporate scandals in USA and UK.

SECP and State Bank of Pakistan have initiated numerous reforms aimed at improving corporate governance mechanism in Pakistan. In the midst of these, the vital development is the implementation of the code of Corporate Governance in Pakistan in 2002; which was substantially revised in 2012. Pakistan Institute of 
Corporate Governance (PICG) was established in 2004, it increases awareness and champions the derivation of good governance practices, and it develops professionalism and encourages engagement of corporate bodies and individuals into the role of overseeing efficiency.

\section{LITERATURE REVIEW \& HYPOTHESES}

CEO duality is considered as one of the most discussed and controversial topics in corporate governance literature (Abdullah 2004; Fosberg 2004; Wang et al. 2014), which provides persuasive, but competing, predictions (Rechner \& Dalton 1991). The board is a governance mechanism in agency framework, for strategic decision making and setting organization vision (Abdullah 2004), by the supposition that when the shareholders have the information to verify and influence supervision deeds, the executives are more likely to act in the interests of the shareholders.

Moreover, agency theorists put forward one key monitoring feature which is the separation between the roles of the CEO and chairman (Abdullah 2004; Li \& Li 2009). According to this view, duality may blight the board's ability to watch for executive opportunism (Daily \& Dalton 1993) because the powerful chief executive is able to control the board. Moreover, agency theorist claims that a powerful leader holding both the CEO and board chairman positions will tend to pursue his personal interests more willingly than for the benefit of the principal (Weisbach 1988). An individual with dual positions will tend to operate ceremonially, communicate poorly and "rubber-stamp" the executive's verdicts (Chen \& Young 2009 and Hu et al. 2009).

On the other hand, the separation of CEO and chairman positions sends positive signals to corporate lenders and investors. Hence, increases the chances of raising additional capital that reduces the risk of bankruptcy. Yermack (1996) reported that firms are more valuable when the CEO and chairman's offices are held separately. Fosberg (2004) opined that in firms where the positions of CEO and chairman are clearly separated, the level of debt in their capital structure is most likely to be optimally employed. Besides, Ehikioya \& Benjami (2009) discovered that for firms in which their CEO and Board chairman are separated, stakeholders are likely to gain confidence in the firms' ability to raise additional capital; and hence, there are less chances of bankruptcy.

CEOs have higher fiduciary powers, stemming from their hierarchical role and relational power, based on proficiency and esteem, than the board (Stiles 2001). However, both leading positions achieve by same persona, not only greater formal authority over board members, but also an increased informal influence over board processes (Allan \& Widman 2000).

Accordingly, duality has been disparaged as it curtails monitoring (Zajac \& Westphal 1994). Thus, those who demand for the restructuring of corporate governance mechanism stress on the significance of attentive monitoring afforded by the absence of duality (Lorsch \& MacIver 1989 and Stiles 2001). This is an interesting argument to those who want these two positions split. However, Stiles (2001) disagreed, in view of the implication of acquisitions and potential agency issues concerned; whereby through the backing of agency theory, it is anticipated that the duality will be more likely to affect acquisition performance negatively.

Conversely, stewardship theory offers a complementary perception; stating that agents are good stewards to company resources and can lead to efficient company (Donaldson \& Davis 1991).

Gillan (2006) found a positive relationship between CEO duality and firm financial performance. Further, Faleye (2007) showed that CEO duality is positively related to organizational complexity, CEO reputation and managerial ownership. This finding is in line with Peng, Zhang and Li (2007) and their findings on CEO duality strongly support the stewardship theory.

Proponents of stewardship theory argued that stability in leadership structure should have a number of advantages, as it allows lucid delineation of leadership and control responsibilities; that over time are well understood by management, board members, and the investors (Boyd, 1995; Daily \& Dalton 1997). Meanwhile, Finkelstein \& D’Aveni (1994), Leng (2004), Adams et al. (2005), Gillan (2006), Kroll et al. (2008) and Jackling \& Johl (2009) showed that the shareholders' benefits are improved by combining the roles of chairman and CEO.

Stewardship theory yields a contrasting hypothesis regarding acquisition performance. If it is true that CEO duality results in more consistent strategies' formulation and implementation; and subsequently better firm performance, then the effects of acquisition announcement should be positive. Hence, from the above review of literature, we conjecture that the effect of CEO on firm performance is unresolved, which requires an investigation on a strong relationship between CEO duality and firm performance. Therefore, under the stewardship framework, it is hypothesized that: $\mathrm{H}_{1}$ : There is a positive association between CEO duality
and firm performance.

There is an increasing body of research which shows that there is not a single model that adequately portrays corporate governance in all national contexts (La Porta et al. 1997 \& 1998). Firms in developing countries have different institutional expectations than in developed countries, and such different institutional contexts may lead to a different relationship with firm performance (Judge et al. 2003; Abdullah 2004). Due to this prospective, developing countries do not endorse the appointments of chairman from the CEO of the same company in their respective code of corporate governance. The UK Combined Code on Corporate Governance states that "a chief executive should not go on to be chairman of the same company. If exceptionally a board decides 
that a chief executive should become chairman, the board should consult major shareholders in advance and should set out its reasons to shareholders at the time of the appointment and in the next annual report" (p. 7).

The code of corporate governance 2002 in Pakistan states that "The Chairman of a listed company shall preferably be elected from among the non-executive directors of the listed company. The Board of Directors shall clearly define the respective roles and responsibilities of the Chairman and Chief Executive, whether or not these offices are held by separate individuals or the same individual." (Clause ix, p. 3)

The recent empirical research on CEO duality reveal mixed and inconclusive picture both in developing and developed countries. While a number of studies supported CEO duality, several others concluded otherwise; and an additional set of studies (Dalton et al. 1998 and Dahya 2004) did not reveal significant relationships between leadership structure and firm performance. To recap on the earlier theoretical discussion, the results provide support that duality does not affect firm performance (Dahya et al. 1996; Laing \& Weir 1999; Dedman 2000; Franks et al. 2001; Rhoades et al. 2001; Weir et al. 2002; Higgs 2003; Leng 2004; Kao \& Chen 2004; Xie et al. 2003; Davidson et al. 2005 and Abdul Rahman \& Mohamed Ali 2006).

Brickley, Coles, \& Jarrell (1997) showed that CEO duality is not associated with inferior performance; while Baliga, Moyer, and Rao (1996) concluded that there are no discernible differences in performance that can be attributed to a firm's leadership structure. There are studies which also noticed that the association between CEO duality and firm performance is moderated by family control factor (Ballinger \& Marcel 2010; Elsaid \& Davidson 2009 and Elsaid, Davidson \& Benson 2009). Nonetheless, although most of the empirical researches on the relationship between CEO duality and firm performance focused on large corporations (Dalton et al. 1998), some recent papers researched on transition economies.
Figure 1 represents the CEO's influence in the related tasks and we can see from this figure that the CEO's level of activity is quite high in all the tasks and it is foreseeable that the CEOs in the Pakistani public listed companies are involved in most of the firm's areas. Figure 1 also indicates that the CEO's power has two different tendencies. Foremost, there are two tasks in which the CEO's powers are high; fiduciary duties and operational function. This is consistent with the fact that these are basic CEO's tasks. In contrast, there are three tasks where the CEO has less power; succession plan, policy making and design, and implement strategic vision. This is a clear indication of the increasing role being played by the board of directors in strategic management.

\section{METHODOLOGY}

For this study, a sample of 100 companies were taken from Karachi Stock Exchange (KSE) 100 indexed companies from 2007 to 2011 (five years). Five companies were excluded due to non availability of data or missing data. According to the Karachi Stock Exchange official brochure "The KSE-100 Index was introduced in November 1991 with a base value of 1,000 points. The KSE - 100 Index comprises of 100 selected companies on the basis of sector representation and highest market capitalization, which capture over $90 \%$ of total market capitalization of companies listed on the Exchange."

The sample's selection procedure was based on sectors. From the 33 sectors, 32 companies were selected, i.e. one company from each sector (excluding Open-End Mutual Fund Sector) on the basis of the largest market capitalization and the remaining 66 companies were selected on the basis of largest market capitalization in descending order; where this is based a total return index, i.e. dividend, bonus and rights are adjusted.

Data on obligatory variables was collected through secondary sources. Meanwhile, data on corporate governance internal mechanism was collected through corporate information pages, the code of corporate governance

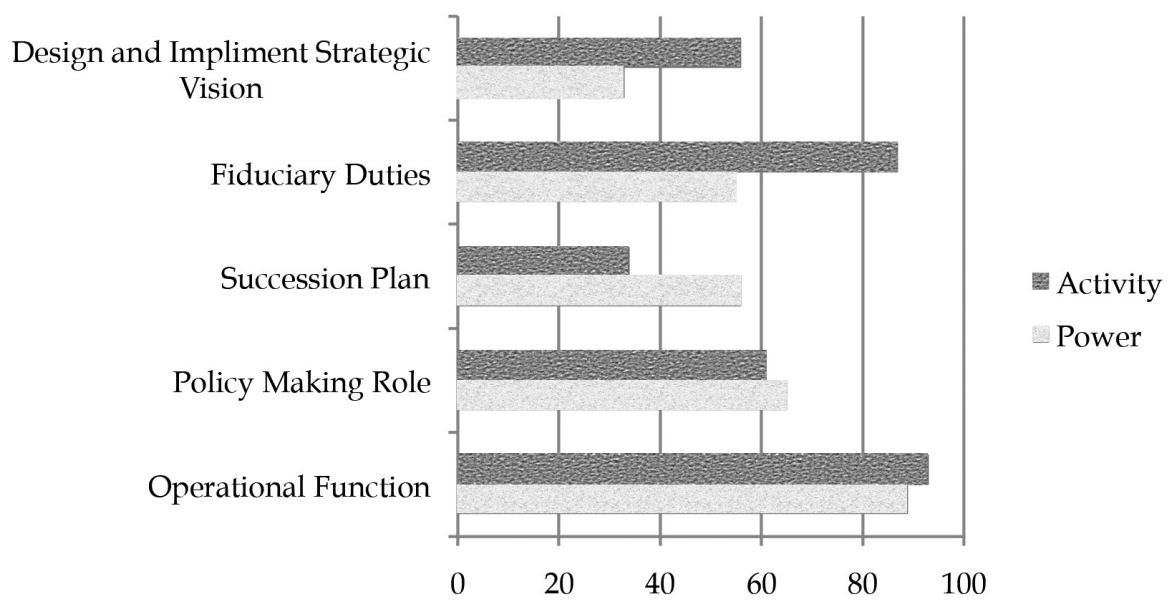

FIGURE 1. Comparison on Basic CEO Tasks 
compliance report, directors' profiles and directors' report to the shareholders. Data related to the financial part of the study was collected from financial statement section of Annual Reports. Table 1 represents the data set of five years on the basis of availability.

Table 2 illustrates the summary of the dual characteristics of the sample; i.e. Dual CEO position and separate CEO position. The result indicates that for family firms, $85 \%$ (402) of them have a separate position for CEO, in contrast to $15 \%$ (73) in dual CEO position. Interestingly, the average year of affiliation with the firm in separate CEO /chair is 9 years, while the affiliation of CEO with the firm is 12 years in the case of duality.

Particularly, prior research showed that shorter CEO decision horizon has a significant agency cost (Antia, Pantzalis \& Park 2010), and thus, CEO tenure is controlled as the impact of firms having long- serving CEOs cannot be easily undone, which might arises due to the CEO's lack of discipline which results in firm's poor performance (Berrone \& Gomez-Mejia 2009; Lau, Sinnadurai \& Wright 2009). Moreover, $84 \%$ (301) of CEOs have postgraduate qualifications if they are only the CEO; but in duality, only $16 \%$ (59) of the CEOs have postgraduate or professional qualification.

\section{MULTIVARIATE REGRESSION MODELS}

This study applies multivariate regression analysis to test the relationship between CEO duality and firm performance. The underlying assumption is that the multiple regression model is used to check the multicollinearity based on the correlation matrix as well as the variance factors (Yermack, 1996; Boyd, 1995). Therefore, the following regression equation is proposed:

$$
\text { Performance }=\alpha+\beta_{1} \text { CEO DUAL }+\beta_{2} \text { Control }+\in
$$

\section{VARIABLES DESCRIPTION}

Table 3 provides the variables description.

Performance Variables The variables employed for firm profitability were Economic Value Added (EVA), Return on Assets (ROA), Tobin's Q and Earnings Per Share (EPS).

Economic Value Added (EVA) was popularized by a management consultancy firm, Stern Stewart \& Company. It is a mechanism (which is accounting-based) simplified as the following:

$$
\begin{aligned}
\text { EVA }= & \text { Operating Profit after tax }-(\text { Operating } \\
& \text { expenses }- \text { Invested Capital })
\end{aligned}
$$

Return on Assets (ROA) also known as return on investment, measures how a company's assets are generating profits for the company, or earnings from assets. It is measured by dividing earnings or net income, in this case annual earnings or net income, of the company's total assets for the same fiscal period.

Tobin's Q is defined as the ratio of the market value of equity and market value debt to replacement costs of firm's assets. In Pakistan, as some other developing countries, there is no active market for debt. Khana \& Palepu (1999) argued that using market-based indicator is inappropriate in emerging countries where illiquid and thin trading market dictate the absence of efficient capital market.

Earnings per Share (EPS), one of the commonly accepted measures, is employed to determine the impact of independent and moderating variables. EPS measures the worth to shareholders on the earnings attributable to each ordinary share over the time; and is calculated as net profit divided by number of ordinary shares, multiplied by the percentage (Abdullah 2004; Iyengar \& Zampelli 2009).

TABLE 1 . Yearly Set of dual CEO sample

\begin{tabular}{cccccc}
\hline \multirow{2}{*}{ Year } & \multicolumn{2}{c}{ Combine } & \multicolumn{2}{c}{ Split } & \multirow{2}{*}{ Total } \\
\cline { 2 - 4 } & Number of Firms & Percentage & Number of Firms & Percentage & \\
\hline 2007 & 14 & $15 \%$ & 81 & $85 \%$ & 95 \\
2008 & 12 & $13 \%$ & 83 & $87 \%$ & 95 \\
2009 & 15 & $16 \%$ & 80 & $84 \%$ & 95 \\
2010 & 16 & $17 \%$ & 79 & $83 \%$ & 95 \\
2011 & 16 & $17 \%$ & 79 & $83 \%$ & 95 \\
\hline
\end{tabular}

TABLE 2. CEO duality characteristics

\begin{tabular}{lcc}
\hline Characteristic & Split & Combine \\
\hline Have Family Relations & 402 & 73 \\
Tenure with the firm & 9 years & 12 years \\
Ownership of firm equity & $6.89 \%$ & $2.38 \%$ \\
Postgraduate CEO & 301 & 59 \\
Avg. CEO Age & 55 & 54 \\
Female CEO & 7 & 8 \\
\hline
\end{tabular}


TABLE 3. Description of Variables

\begin{tabular}{|c|c|c|c|}
\hline \multicolumn{4}{|c|}{ Governance Variables } \\
\hline (A) & CEO Duality (DUAL) & \multicolumn{2}{|c|}{ Binary variable indicating 1 if CEO Duality, or - 0 otherwise. } \\
\hline \multicolumn{4}{|c|}{ Performance Variable } \\
\hline (B) & Return on Assets (ROA) & & Net Profit divided by Total Assets \\
\hline (C) & Tobin's Q (Q) & & $\begin{array}{l}\text { The book value of debt plus the market value of equity, divided } \\
\text { by the book value of assets. }\end{array}$ \\
\hline (D) & Economic Value (EVA) & Added & $\begin{array}{l}\text { Net Operating Profit After Taxation (NOPAT) } \\
\text { Weighted average cost of capital (WACC) } \\
\text { Invested Capital (IC) }\end{array}$ \\
\hline & & & EVA $=$ NOPAT $-($ WACC $\times$ IC $)$ \\
\hline (E) & Earnings Per Share (EPS) & & Net income/weighted average of common shares outstanding. \\
\hline \multicolumn{4}{|c|}{ Controll Variables } \\
\hline (F) & Financial Leverage (FL) & & Total Debt/Total Equity \\
\hline (G) & Firm Size (FSIZE) & & Natural Logarithm of Total Assets \\
\hline$(\mathrm{H})$ & Firm Age (FAGE) & & Total number of years the company incorporated \\
\hline (I) & CEO Shareholding & & The percentage of ownership held by the CEO in the firm. \\
\hline$(\mathrm{J})$ & Gender Diversity & & Binary variable indicating 1 if female CEO, or - 0 otherwise. \\
\hline$(\mathrm{K})$ & CEO Age & & The number of years of CEO age. \\
\hline$(\mathrm{L})$ & CEO Qualification & & $\begin{array}{l}\text { Binary variable indicating } 1 \text { if CEO holds Master degree or } \\
\text { professional qualification, or }-0 \text { otherwise. }\end{array}$ \\
\hline (M) & CEO Tenure & & The number of years of CEO affiliation with the firm. \\
\hline
\end{tabular}

Dependent Variable CEO duality (DUAL) is a dummy variable that assumes the value one if the firm's CEO and Chairman of the Board is the same person, or zero if otherwise (Berg \& Smith 1978; Rechner \& Dalton 1991; Boyd 1995; Frankforter et al. 2007; Henry 2009; Kim et al. 2009; Wang et al. 2014). Meanwhile, Lam and Lee (2008) observed that the separation of these rules does not necessarily improve a board's monitoring capability if the CEO and Chairman of the Board belong to the same family. Therefore, following Lei and Song (2004) and Lam and Lee (2008) we consider CEO duality as the observations in which these two roles are performed by the same person.

Controll Variable Ahmed et al. (2006) argued that financial leverage may lead to improved external control because creditors would monitor capital structure more intensively in order to protect their interests. Accordingly, Chen and Jaggi (2000) stated that financial leverage (FL) is used to measure firm leverage. CEO tenure is measured as the number of years that the CEO being employed by the firm (frankfurter et al. 2007 and Kim et al. 2009).

CEO education has an impact on corporate performance, including innovation, strategic choices, and risk taking (Matta \& Beamish 2008 and Zhang \& Rajagopalan 2010). Thus, CEO education was also controlled in order to avoid influence on duality-firm performance (Ling, Simsek, Lubatkin, \& Veiga 2008).
Previous empirical studies demonstrated that firm performance is negatively related to total assets (Lang \& Stulz 1994). Therefore, in order to control for firm size, we included the variables natural logarithm of total assets (FSIZE). Firm age was calculated as the natural logarithm of the number of years from the incorporation of the firm, which helped to control for organization's maturity (Arthurs et al. 2008 and Matta \& Beamish 2008). The logarithmic form of analysis was applied to reduce heteroskedasticity (Finkelstein \& D'Aveni 1994).

\section{DATA ANALYSIS}

\section{DESCRIPTIVE STATISTICS}

Tables 4 and 5 depict the descriptive statistics for the variables used in our analysis. Table 4 segregates the data into Dual CEO (73 companies) and Separate CEO (402 companies). The maximum CEO shareholding percentage is double in firms with dual CEO (58\%) as compared to firms with separate CEO (30\%), while the mean is more than double in dual CEO and separate CEO at 6.88 and 2.39 , respectively.

Results of descriptive statistics indicate that in terms of gender, $11 \%$ of combined-role companies have female CEOs; but in contrast, there is only $1.7 \%$ in splitCEO companies. The average age of CEO in both types of companies is approximately the same, but CEO's tenure 
TABLE 4. Descriptive Statistics (Dual and non-dual basis)

\begin{tabular}{|c|c|c|c|c|c|c|c|c|c|}
\hline \multirow[t]{2}{*}{ Variables } & \multicolumn{4}{|c|}{ Dual CEO (N=73) } & \multicolumn{4}{|c|}{ Separate CEO $(N=402)$} & \multirow[t]{2}{*}{ t-value } \\
\hline & Min & Max & Mean & S.D & Min & Max & Mean & S.D & \\
\hline CEO Duality & 0 & 0 & 0.00 & 0.0 & 1 & 1 & 1.00 & 1.00 & $1.00 * *$ \\
\hline CEO Shareholding & 0.00 & 58.00 & 6.88 & 15.06 & 0.00 & 30.00 & 2.39 & 5.32 & $8.58 * *$ \\
\hline Gender Diversity & 0.0 & 1.0 & 0.11 & 0.315 & 0.0 & 1.0 & 0.017 & 0.13 & $3.93 * *$ \\
\hline CEO Age & 43 & 60 & 54.95 & 3.86 & 21 & 70 & 54.19 & 6.73 & $185.7 * *$ \\
\hline CEO Tenure & 1 & 24 & 12.25 & 5.98 & 1 & 32 & 9.03 & 6.14 & $33.37 * *$ \\
\hline CEO Qualification & 0.0 & 1.0 & 0.81 & 0.39 & 0 & 1 & 0.75 & 0.44 & $38.52 * *$ \\
\hline Firm Age & 7 & 65 & 33.64 & 18.94 & 5 & 152 & 37.83 & 27.83 & $30.37 * *$ \\
\hline Firm Size & 6.20 & 8.98 & 7.23 & 0.71 & 5.11 & 9.06 & 7.427 & 0.698 & $229.3 * *$ \\
\hline Financial Leverage & 0.00 & 3.61 & 0.211 & 0.512 & 0.00 & 1.99 & 0.14 & 0.193 & $12.01 * *$ \\
\hline Economic Value Added & 0 & 1 & 0.40 & 0.49 & 0 & 1 & 0.37 & 0.483 & $16.78^{* *}$ \\
\hline Return on Assets (ROA) & -0.25 & 0.35 & 0.096 & 0.108 & -0.88 & 0.53 & 0.065 & 0.138 & $11.29 * *$ \\
\hline Earnings per Share (EPS) & -25.20 & 255 & 21.39 & 52.78 & -26.35 & 300.87 & 15.03 & 33.8 & $9.34 * *$ \\
\hline Tobin's Q & 0.06 & 5.52 & 1.26 & 1.1937 & 0.05 & 9.16 & 0.99 & 1.072 & $20.59 * *$ \\
\hline
\end{tabular}

TABLE 5. Descriptive Statistics of all variables

\begin{tabular}{lcccc}
\hline Variables & Min. & Max. & Mean & S.D. \\
\hline$\quad$ Governance & & & & \\
CEO Duality & 0 & 1 & 0.15 & 1.39 \\
$\quad$ Control & & & & \\
CEO Shareholding & 0.00 & 58.00 & 3.076 & 7.813 \\
Gender Diversity & 0.0 & 1.0 & 0.032 & 0.175 \\
CEO Age & 21 & 70 & 54.31 & 6.375 \\
CEO Tenure & 1 & 32 & 9.52 & 6.221 \\
CEO Qualification & 0.0 & 1.0 & 0.758 & 0.429 \\
Firm Age & 5 & 152 & 37.19 & 26.683 \\
Firm Size & 5.11 & 9.06 & 7.397 & 0.703 \\
Financial Leverage & 0.00 & 3.61 & 0.148 & 0.268 \\
$\quad$ & & & \\
$\quad$ Performance & & 1 & 0.37 & 0.484 \\
Economic Value Added (EVA) & 0 & 0.53 & 0.069 & 0.135 \\
Earnings per Share (EPS) & -0.88 & 300.87 & 16.003 & 37.346 \\
Tobin's Q & -26.35 & 9.16 & 1.035 & 1.0948 \\
\hline
\end{tabular}

is 12 years in combined-role companies and 9 years in separate-role companies, which indicates that the person holding dual roles in Pakistan normally has long affiliation with the same firm.

On the average, Dual CEO companies have qualified CEO ( $81 \%$ holding master degree) while $75 \%$ of the split CEO have master degree. The maximum age of firm for separate CEO is 152 years (that is the oldest listed companies in the Karachi stock exchange) instead of 65 years of incorporation of the dual-CEO firm.

Table 5 indicates the descriptive results for all sample companies. CEO duality was found in $15.4 \%$ of our sample (73 out of 475 firms), having family relationships taken into consideration. In a previous study on developing economy, CEO duality ratios ranged between $42 \%$ and $25 \%$ (Andrade et al. 2008). This downward trend in CEO duality may indicate that Pakistani firms are progressively adopting the code of corporate governance.
Of sampled firms, $37 \%$ have positive economic value added (EVA) and the remaining $63 \%$ represent economic loss. The value of Earnings per Share (EPS) is highly diverse; at -26.35 (minimum) to 300.87 (maximum).

\section{CORRELATION COEFFICIENT ANALYSIS}

The Pearson correlation coefficients are presented in Table 6 . The results revealed that $\mathrm{CEO} /$ Chairman duality do not have positive association with any performance variables. Subsequently, Economic Value Added (EVA) is negatively correlated with CEO Duality. Meanwhile, the duality is negatively correlated with the percentage of CEO shareholding, female CEO, CEO's years of affiliation and financial leverage; but is positively correlated with the firm size (FSIZE). 


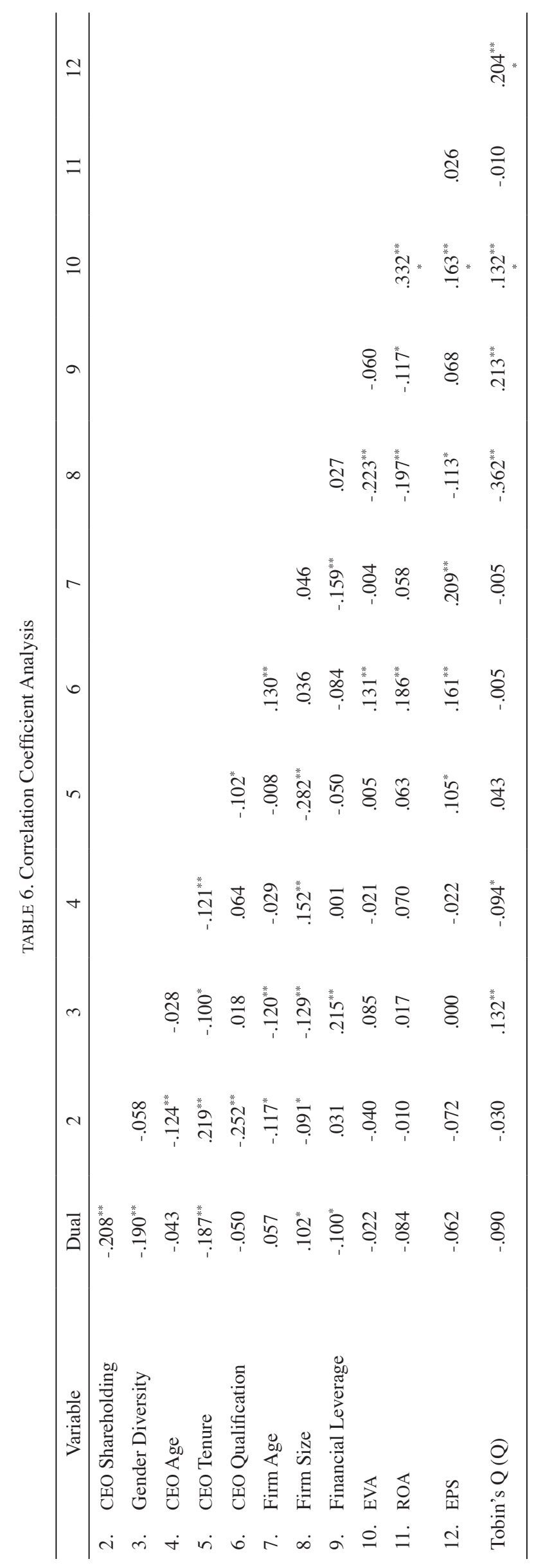




\section{REGRESSION ANALYSIS}

Table 7 presents regression coefficients for the dependent variables of Economic Value Added (EVA). Model 1 examines the effect of controlled variables on firm performance. Interestingly, EVA explained $7.7 \%$ of the total variance in firm performance. Results conclude that the higher qualification of the CEO $(\beta=0.007, p<0.05)$ is positively, while firm size $(\beta=0.000, \mathrm{p}<0.05)$ is negatively, associated with the economic performance of the firm. The main result indicates that there is not any association between EVA and CEO duality.

Table 8 presents regression coefficients for dependent variables of Return on Assets (ROA). Model 2 examines the effect of controlled variables on firm performance. ROA explained $9.6 \%$ of the total variance in firm performance. Results conclude that the higher qualification of the CEO $(\beta=0.000, p<0.05)$ and CEO age (AGE) $(\beta=0.039, \mathrm{p}<0.05)$, are positively associated with the ROA; but firm size (FSIZE) is negatively associated with the firm performance. The main result also indicates that there is not any association between ROA and CEO duality.
The dependent variable, Tobin's Q (Q) and the regression coefficient analysis are presented in Table 9. Model 2 examines the effect of dual leadership structure and controlled variables on firm performance. Tobin's Q explained $19.2 \%$ of the total variance in firm performance. However, the results indicate that Q has a positive association with financial leverage, but a negative association with firm size. However, we did not find any association with CEO duality $(\beta=0.218, \mathrm{p}<0.05)$.

Table 10 presents a regression coefficient analysis for the dependent variable, Earnings per Share (EPS). Model 2 examines the effects of independent variable (CEO/Chair Duality) and controll variables on firm performance. EPS explained $10.3 \%$ of the total variance in firm performance. However, the results indicate that EPS has a positive association with CEO qualification, CEO affiliation with the firm, firm age, firm size and financial leverage; but we did not find any association with CEO duality $(\beta=0.392$, $\mathrm{p}<0.05)$.

Table 11 presents the summary of the significant variables with the performance and the association of the

TABLE 7. Results of Regression Analysis (Dependent Variable EVA)

\begin{tabular}{lcccc}
\hline \multicolumn{1}{c}{ Variables } & $(1)$ & $(2)$ & $(3)$ & $(4)$ \\
\hline CEO Shareholding & 0.735 & 0.754 & 0.840 & \\
Gender Diversity & 0.207 & 0.212 & 0.074 & \\
CEO Age & 0.994 & 0.988 & 0.591 & \\
CEO Tenure & 0.396 & 0.412 & 0.581 & \\
CEO Qualification & 0.007 & 0.007 & 0.006 & \\
Firm Age & 0.752 & 0.751 & & 0.958 \\
Firm Size & 0.000 & $(0.000)$ & & $(0.000)$ \\
Financial Leverage & 0.195 & 0.199 & & 0.229 \\
CEO Duality & & 0.939 & 0.956 & 0.919 \\
& & & & \\
$\mathrm{R}^{2}$ & 27.7 & 27.7 & 22.5 & 25.3 \\
Adjusted $\mathrm{R}^{2}$ & 26.1 & 25.9 & 21.3 & 24.5 \\
$\mathrm{~F}$ & 4.875 & 4.325 & 2.024 & 6.559 \\
F for $\Delta \mathrm{R}^{2}$ & 0.000 & 0.000 & 0.061 & 0.000 \\
\hline
\end{tabular}

TABLE 8. Results of Regression Analysis (Dependent Variable ROA)

\begin{tabular}{lcccc}
\hline Variables & $(1)$ & $(2)$ & $(3)$ & $(4)$ \\
\hline CEO Shareholding & 0.490 & 0.664 & 0.688 & \\
Gender Diversity & 0.676 & 0.855 & 0.748 & \\
CEO Age & 0.029 & 0.039 & 0.137 & \\
CEO Tenure & 0.575 & 0.723 & 0.098 & \\
CEO Qualification & 0.000 & 0.000 & 0.000 & \\
Firm Age & 0.410 & 0.405 & & 0.241 \\
Firm Size & $(0.000)$ & $(0.000)$ & & $0.000)$ \\
Financial Leverage & 0.039 & 0.033 & & 0.014 \\
CEO Duality & & 0.262 & 0.304 & 0.081 \\
& & & & \\
$\mathrm{R}^{2}$ & 19.6 & 19.9 & 15.0 & 16.0 \\
Adjusted R & 18.1 & 18.1 & 13.8 & 15.2 \\
F & 6.220 & 5.672 & 4.083 & 7.476 \\
F for $\Delta \mathrm{R}^{2}$ & 0.000 & 0.000 & 0.001 & 0.000 \\
\hline
\end{tabular}


research's main variable, CEO/Chair duality. Results in Table 11 generally suggest that CEO duality has no negative or positive effect with firm performance. These results are broadly consistent with the findings in other studies (Annuar \& Shamsher 1994 and Fosberg 1989).

In order to establish the level and direction of regression analysis, among the variables of interest, above is the Regression Analysis Matrix (Abdullah 2004). This matrix attempts to provide insights to the hypothesis tests that the study intended to test. It can be observed that we reject the hypothesis that there is a significant positive relationship between CEO Duality and performance of firms at the Karachi Stock Exchange (KSE).

In summary, the empirical results support the hypothesis that in firms where the positions of CEO and Chairman of the Board being held by the same person, no effect on their performance can be observed.

\section{CONCLUSION}

Academic research suggests that firm performance is associated with board leadership structures. The purpose of the study is to investigate the relationship between CEO duality and the performance of Pakistani public listed companies for the period of 2007 to 2011 . The theoretical and empirical literature on corporate governance offers two alternative perspectives.

The agency theory advocates that the separation of the two roles is an important determinant to a board's independence and effectiveness. Conversely, the stewardship theory postulates that firms with a unified leadership structure operate more efficiently through better coordination and unambiguous command, thus deal more effectively with strategic challenges. The leadership structure of the majority of Pakistani companies is characterized by the separation of roles of CEO and chairman.

Our empirical findings provide clear answers to the emerging issue in developing countries. We find significant differences in firm's characteristics between dual and non-dual CEO firms. However, our multivariate tests find no evidence that CEO duality has a significant effect on firm performance. Our evidence casts doubt on the notion that firms changing from duality to non-dual

TABLE 9. Results of Regression Analysis (Dependent Variable Q)

\begin{tabular}{lcccc}
\hline Variables & $(1)$ & $(2)$ & $(3)$ & $(4)$ \\
\hline CEO Shareholding & 0.180 & 0.116 & 0.192 & \\
Gender Diversity & 0.471 & 0.649 & 0.015 & \\
CEO Age & 0.260 & 0.214 & 0.037 & \\
CEO Tenure & 0.364 & 0.267 & 0.402 & \\
CEO Qualification & 0.908 & 0.969 & 0.722 & \\
Firm Age & 0.323 & 0.319 & & 0.236 \\
Firm Size & $(0.00)$ & $(0.000)$ & & $(0.00)$ \\
Financial Leverage & 0.000 & 0.000 & & 0.000 \\
CEO Duality & & 0.218 & 0.106 & 0.437 \\
& & & & \\
$\mathrm{R}^{2}$ & 29.2 & 29.5 & 23.5 & 18.4 \\
Adjusted R & 27.8 & 27.9 & 22.3 & 17.7 \\
$\mathrm{~F}$ & 13.845 & 12.49 & 2.836 & 26.50 \\
F for $\Delta \mathrm{R}^{2}$ & 0.000 & 0.000 & 0.010 & 0.000 \\
\hline
\end{tabular}

TABLE 10. Results of Regression Analysis (Dependent Variable EPS)

\begin{tabular}{lcccc}
\hline Variables & $(1)$ & $(2)$ & $(3)$ & $(4)$ \\
\hline CEO Shareholding & 0.299 & 0.231 & 0.131 & \\
Gender Diversity & 0.812 & 0.684 & 0.916 & \\
CEO Age & 0.944 & 0.878 & 0.533 & \\
CEO Tenure & 0.024 & 0.039 & 0.010 & \\
CEO Qualification & 0.001 & 0.002 & 0.001 & \\
Firm Age & 0.000 & 0.000 & & 0.000 \\
Firm Size & 0.024 & 0.025 & & 0.007 \\
Financial Leverage & 0.006 & 0.007 & & 0.022 \\
CEO Duality & & 0.392 & 0.319 & 0.246 \\
& & & & \\
$\mathrm{R}^{2}$ & 10.3 & 10.4 & 4.7 & 7.3 \\
Adjusted R & 8.7 & 8.7 & 3.5 & 6.5 \\
$\mathrm{~F}$ & 6.674 & 6.010 & 3.827 & 9.251 \\
F for $\Delta \mathrm{R}^{2}$ & 0.000 & 0.000 & 0.001 & 0.000 \\
\hline
\end{tabular}


TABLE 11. Statistical Test Findings

\begin{tabular}{|c|c|c|c|}
\hline \multirow{2}{*}{$\begin{array}{c}\text { Dependent } \\
\text { Variable }\end{array}$} & \multirow[t]{2}{*}{ Variable } & \multicolumn{2}{|c|}{ Asymptotic Significance } \\
\hline & & Not significant & Significant \\
\hline \multirow{3}{*}{ EVA } & CEO Qualification & & 0.007 \\
\hline & Firm Size & & $(0.000)$ \\
\hline & CEO Duality & 0.939 & \\
\hline \multirow{3}{*}{ ROA } & CEO Qualification & & 0.000 \\
\hline & Firm Size & & $(0.000)$ \\
\hline & CEO Duality & 0.262 & \\
\hline \multirow{6}{*}{ EPS } & CEO Tenure & & $(0.039)$ \\
\hline & CEO Qualification & & 0.002 \\
\hline & Firm Age & & 0.000 \\
\hline & Firm Size & & $(0.025)$ \\
\hline & Financial Leverage & & 0.007 \\
\hline & CEO Duality & 0.392 & \\
\hline \multirow[t]{3}{*}{ Tobin's Q } & Firm Size & & $(0.000)$ \\
\hline & Financial Leverage & & 0.000 \\
\hline & CEO Duality & 0.218 & \\
\hline
\end{tabular}

leadership structure would experience improvement in their performance. The above results are supported by prior researches on the relationship between separate leadership structure and firm performance. The results are consistent with the studies conducted by Vance (1978); Sullivan (1988); Rechner \& Dalton (1989); Leng (2004); Dahya, Galguera-Garcia \& Bommel (2009) and Yasser (2011) where they reported that duality is not significant to firm performance.

According to Abdullah (2004), combined leadership (either single or joint) is not related to performance because financial ratios may not capture the board and leadership roles in establishing a firm's value, but long term measures such as firms' growth and their share prices might be useful measures. An implication for further research in Pakistan relates to several areas of "boundary conditions" of the agency, stewardship and organizational theories in corporate governance (Yammeesri \& Herath 2010; Yasser 2011). Multidisciplinary studies of this nature may contribute to a better understanding of what drives the effectiveness of leadership structure in Pakistan. For example, future work can investigate the specific situations and circumstances in which CEO duality may be beneficial to Pakistani firms. Investigating the factors of board's effectiveness with multiple theoretical lenses may help develop more effective corporate governance models.

In view that our study is a first step in many regards, its limitations should be noted. First, this study is based on KSE-100 companies from 2007 to 2011; however, a large sample and more recent data are required. Second, we focused on relatively large, publicly traded firms (KSE 100), suggesting that our results may not extend to smaller firms. Small firms tend to have lesser public scrutiny than large firms, indicating that accountability and independence play an even larger role in minimizing agency conflicts. Although this study focused on the role of CEO duality and firm performance, future researchers should consider panel data analysis for better results.

CEO duality is good for some firms, while it is the opposite for other firms (Boyd 1995; Brickley et al. 1997; Elsayed 2007); a particular firm may adopt CEO duality under an appropriate or inappropriate organizational condition (Kang and Zardkoohi 2005). Likewise, it is too early to draw a conclusion and further study may also be conducted to examine the industry-specific impact of board leadership structure and firm performance in emerging economies.

\section{REFERENCES}

Andrade, L., Ashmos, P. \& Duchon, D. 2008. Getting Past Conflict Resolution: A Complexity View of Conflict. E:CO 10(1): 23-38.

Abdul Rahman, R. \& Mohamed Ali, F.H. 2006. Board, audit committee, culture and earnings management: Malaysian evidence. Managerial Auditing Journal 21(7): 783-804.

Abdullah, S. 2004. Board Composition, CEO Duality and Performances Among Malaysian Listed Companies. Corporate Governance 4(4): 47-61.

Adams, R.B., Almeida, H. \& Ferreira, D. 2005. Powerful CEOs and Their Impact on Corporate Performance. Review of Financial Studies 18(4): 1403-1432.

Albrecht, W.S. \& Albrecht, C.O. 2004. Fraud and corporate executives. Agency, Stewardship and Broken Trust. Journal of Forensic Accounting 5: 109-130.

Allan, P. \& Widman, A. 2000. A comparison of the views of CEOs and public pension funds on the corporate governance issues of chairman-CEO duality and election of lead directors. American Business Review 18(1): 49-54.

Annuar, M.N. \& Shamsher, M. 1994. The Wealth Effect of Appointments and Resignations of Board of Directors. The Malaysian Management Review 29(2): 44-52.

Arslan, M., Zaman, R., Malik, K. \& Mehmood, A. 2014. Impact of CEO Duality and Audit Committee on Firm Performance: 
A Study of Oil \& Gas Listed Firms of Pakistan. Research Journal of Finance and Accounting 5(17): 1-7.

Arthurs, D., Hoskisson, E., Busenitz, L. Johnson, A. 2008. Managerial Agents Watching Other Agents: Multiple Agency Conflicts Regarding Underpricing in IPO Firms. Academy of Management Journal 51(2): 277-294.

Baliga, B., Moyer, C. \& Rao, S. 1996. CEO duality and Firm Performance: What's the fuss? Strategic Management Journal 17: 41-53.

Ballinger, A. \& Marcel, J. 2010. The use of an interim CEO during succession episodes and firm performance. Strategic Management Journal 31: 262-283.

Berg, S. \& Smith, K. 1978. CEO board chairman. A quantitative study of dual versus unitary leadership. Directors and Boards 3: 34-39.

Berrone, P. \& Gómez-Mejia, L.R. 2009. Environmental Performance and Executive Compensation: An integrated agency-institutional perspective. Academy of Management Journal 52(1): 103-126.

Bhagat, S. \& Bolton, B. 2008. Corporate Governance and Firm Performance. Journal of Corporate Finance 14: 257-273.

Boyd, B. 1995. CEO Duality and Firm Performance: A Contingency Model. Strategic Management Journal 16: 301-312.

Brickley, J., Coles, J. \& Jarrell, G. 1997. Leadership structure: separating the CEO and chairman of the board. Journal of Corporate Finance 3(3): 189-220.

Cadbury Committee. 1992. The Financial Aspects of Corporate Governance. Professional Publishing Ltd: London.

Chahine, S. \& Tohme, N.S. 2009. Is CEO duality always negative? An exploration of CEO duality and ownership structure in the Arab IPO context. Corporate Governance: An International Review 17(2): 123-141.

Charan, R. 2005. Boards That Deliver: Advancing Corporate Governance from Compliance to Competitive Advantage. San Francisco: John Wiley \& Sons.

Chen, C. \& Jaggi, B. 2000. Association between independent nonexecutive directors, family control and financial disclosures in Hong Kong. Journal of Accounting and Public Policy 19: 285-310.

Chen, Y. \& Young, M. 2009. Cross-border mergers and acquisitions by Chinese listed companies: A principal perspective. Asia Pacific Journal of Management 26.

Dahya, J., Galguera-Garcia, L. \& Bommel, J. 2009. One Man Two Hats - What's All the Commotion. Financial Review 44: 179-212.

Dahya, J., Lonie, A.A. \& Power, D.M. 1996. The case for separating, the roles of chairman and CEO: an anaylsis of stockmarket and accounting data. Corporate Governance: An International Review 4: 71-77.

Daily, C. \& Dalton, D. 1993. Board of directors' leadership and structure: control and performance implications. Entrepreneurship Theory and Practice 17(3): 65-81.

Daily, C. \& Dalton, D. 1997. Separate, but not independent: board leadership structure in large corporations. Corporate Governance: An International Review 5(3): 126-136.

Dalton, D. \& Daily, C. \& Ellstrand, A. \& Johnson, J. 1998. Metaanalytic reviews of board composition, leadership structure, and financial performance. Strategic Management Journal 19: 269-290.

Davidson, R., Goodwin-Stewart, J. \& Kent, P. 2005. Internal Governance Structures and Earnings Management. Accounting and Finance 45: 241-267.
Dedman, E. 2000. An investigation into the determinants of UK board structure before and after Cadbury. Corporate Governance: An International Review 8: 133-153.

Donaldson, L. \& Davis, J. 1991. Stewardship theory or agency theory? CEO governance and shareholder returns. Australian Journal of Management 16(1): 49-65.

Ehikioya, F. \& Benjamin, I. 2009. Corporate governance structure and firm performance in developing economies: evidence from Nigeria. Journal of Corporate Governance 9(3): 231-243.

Elsaid, E. \& Benjamin, I. 2009. What happens to CEO compensation following turnover and succession? Quarterly Review of Economics and Finance 49(2): 424-447.

Elsaid, E., Davidson, W. \& Benjamin, B.W. 2009. CEO compensation structure following succession: Evidence of optimal incentives with career concerns. The Quarterly Review of Economis and Finance 49(4): 1389-1409.

Elsayed, K. 2007. Does CEO Duality Eeally Affect Corporate Performance? Corporate Governance: An International Review 15(6): 1203-1214.

Faleye, O. 2007. Classified Boards, Firm Value, and Managerial Entrenchment. Journal of Financial Economics 83(2): 501529.

Finkelstein, S. \& D'Aveni, R. 1994. CEO duality as a doubleedged sword: how boards of directors balance entrenchment avoidance and unity of command. Academy of Management Journal 37(5): 1079-1108

Forsberg, R. 1989. Outside Directors and Managerial Monitoring. Akron Business and Economic Review 20: 24-32.

Fosberg, R.H. 2004. Agency problems and debt financing: Leadership structure effects. Corporate Governance: International Journal of Business in Society 4(1): 31-38.

Frankforter, S., Davis, J., Vollrath, D. \& Hill, V. 2007. Determinants of governance structure among companies: A test of agency theory predictions. International Journal of Management 24(3): 454-462.

Franks, J., Mayer, C. \& Renneboog, L. 2001. Who disciplines management in poorly performing companies? Journal of Financial Intermediation 10: 209-248.

Gillan, S. 2006. Recent Developments in Corporate Governance: An Overview. Journal of Corporate Finance 12: 381-402.

Henry, D. 2009. Agency costs, ownership structure and corporate governance Compliance. Pacific-Basin Finance Journal $24-46$.

Higgs Reports. 2003. Review of the Role and Effectiveness of Non-Executive Directors, Department of Trade and Industry, London.

Iyengar, R.J. \& Zampelli,E.M. 2009. Self-selection, endogeneity, and the relationship between CEO duality and firm performance. Strategic Management Journal 30(10): 10921112.

Jackling, B. \& Johl, S. 2009. Board Structure and Firm Performance: Evidence from India's Top Companies. Corporate Governance: An International Review 17(4): 492-1112.

Judge, W. \& Naoumova, I. \& Koutzevol, N. 2003. Corporate governance and firm performance in Russia: an empirical study. Journal of World Business 38: 385-396.

Kang, E. \& Zardkoohi, A. 2005. Board leadership structure and firm performance. Corporate Governance: An International Review 13(6): 785-799.

Kao, L.F., Chiou, J.R. \& Chen, A. 2004. The Agency Problem, Firm Performance and Monitoring Mechanisms: The 
Evidence from Collateralized Shares in Taiwan. Corporate Governance: An International Review 12: 389-402.

Kim, B., Burns, M.L. \& Prescott, J.E. 2009. The strategic role of the board: the impact of board structure on top management team strategic action capability. Corporate Governance: An International Review 17: 728-743.

Kroll, Y., Walters, S. \& Wright, E. 2008. Board Vigilance, Director Experience, and Corporate Outcomes. Strategic Management Journal 29: 363-382.

La Porta, R. \& Lopez-De-Silanes, F. \& Shleifer, A. \& Vishny, R. 1998. Law and finance. Journal of Political Economy 106: 1113-1155.

La Porta, R. \& Lopez-De-Silanes, F. \& Shleifer, A. 1997. Legal determinants of external finance. Journal of Finance 52: $1131-1150$

Laing, D. \& Weir, C.M. 1999. Governance structures, size and corporate performance in UK Firms. Managements Decision 37(5): 457-464.

Lam, T. \& Lee, S. 2008. CEO duality and firm performance: evidence from Hong Kong. Corporate Governance 8(3): 299-316.

Lang, L., Stulz, R. 1994. Tobin's Q, corporate diversification, and firm performance. Journal of Political Economy 102: $1248-1280$

Lau, J., Sinnadurai, P. \& Wright, S. 2009. Corporate governance and chief executice officer dismissal following poor performance: Australian evidence. Accounting and Finance 49: $161-182$

Lei, A. \& Song, F.M. 2004. Corporate governance and firm valuations: evidence from Hong Kong. Working paper, School of Economics and Finance, The University of Hong Kong, Hong Kong.

Leng,A.C.A. 2004. The impact of corporate governance practices on firms' financial performance: Evidence from Malaysian companies. ASEAN Economic Bulletin 21(3): 308-318.

Ling, Y., Simsek, Z., Lubatkin, M.H. \& Veiga, J.F. 2008. Transformational leadership's role in promoting corporate entrepreneurship: Examining the CEO-TMT interface. Academy of Management Journal 51(3): 557-576.

Lorsch, J.W. \& Maclver, E. 1989. Pawns or potentates: the reality of America's corporate boards. Boston, Massachusetts: Harvard Business School Press.

Matta, E. \& Beamish, P.W. 2008. The accentuated CEO career horizon problem: evidence from international acquisitions. Strategic Management Journal 29: 683-700.

Michael, B. \& Anurag, S. 2007. Should the CEO also be Chair of the Board? An empirical examination of family-controlled public firms. Family Business Review 20(2): 111-126.

Peng, Zhang, \& Li, 2007. CEO duality, organizational slack, and firm performance in China. Asia Pacific Journal of Management 27: 611-624.

Prowse, S. 1999. Corporate Governance: Emerging Issues and Lessons from East Asia. Washington: World Bank.

Rechner, P. \& Dalton, D.R. 1989. The Impact of CEO as Board Chairperson on Corporate Performance. Academy of Management Executive 3(2): 141-143.

Rechner, P. \& Dalton, D. 1991. CEO Duality and Organizational Performance: A Longitudinal Analysis. Strategic Management Journal 12(2): 155-160.

Rhoades, D. \& Rechner, P. \& Sundaramurthy, C. 2001. A Meta-analysis of Board Leadership Structure and Financial Performance: Are Two Heads Better than One? Corporate Governance: An International Review 9(4): 311-319.
Stewart, G.B. 1991. The Quest for Value: A Guide for Senior Managers, Harper Business, New York.

Stiles, P. 2001. The impact of boards on strategy: An empirical examination. Journal of Management Studies 38(5) 27-50.

Sullivan, W.M. 1988. Calling or career: The tensions of modern professional life. In A. Flores (Ed.), Professional ideals (pp 40-46). Belmont, CA: Wadsworth Publishing Company.

Tuggle, C.S., Sirmon, D.G., Reutzel, C.R. \& Bierman, L. 2010 Commanding board of director attention: Investigating how organizational performance and CEO duality affect board member's attention to monitoring. Strategic Management Journal.

Vance, S.C. 1978. Corporate governance: assessing performance by boardroom attributes. Journal of Business Research 6 : 203-220.

Wang, D. \& Sun, D. \& Yu, X. and Zhang, Y. 2014. The impact of CEO duality and ownership on the relationship between organisational slack and firm performance in China. Systems Research and Behavioral Science 3(1): 94-101.

Weir, C., Laing, D. \& McKnight, P. 2002. Internal and External Governance Mechanisms: Their Impact on the Performance of Large UK Companies. Journal of Business Finance and Accounting 29: 579-611.

Xie, B., Davidson, N.W. \& DaDalt, P. 2003. Earnings Management and Corporate Governance: The Roles of the Board and the Audit Committee. Journal of Corporate Finance 9(3): 295-316.

Yammeesri, J. \& Kanthi Herath, S. 2010. Board characteristics and corporate value: Evidence from Thailand. Corporate Governance 10(3).

Yasser, Q.R. 2011. Corporate governance and firm performance: An analysis of family and non-family controlled firms. The Pakistan Development Review 50(1): 47-62.

Yermack, D. 1996. Higher market valuation of companies with a small board of directors. Journal of Financial Economics 40(2): 185-211.

Zajac, E.J. \& Westphal, J.D. 1994. The symbolic Management of CEO Compensation. Administrative Science Quarterly 39(3): 367-390.

Zhang, Y. \& Rajagopalan, N. 2010. Once an outsider, Always an outsider? CEO origin, strategic change, and firm performance. Strategic Management Journal 31(3): 334-346.

Qaiser Rafique Yasser*

House \# 278, C-1,

Wapda Town

Gujranwala Pakistan

Abdullah Al Mamun

231 Sandgate Road,

Birmingham Garden

Shortland, 2287 NSW, Australia

Abdul Rahim Suriya

302, 3rd Floor,

66-C 21 Street,

Commercial Street DHA,

Phase II Extension,

Karachi, Pakistan

Corresponding author; email: qaiser_rafique@hotmail.com 